\title{
Prairie Wildlife-over the Years
}

By W. YANCHINSKI, Naicam, Sask.

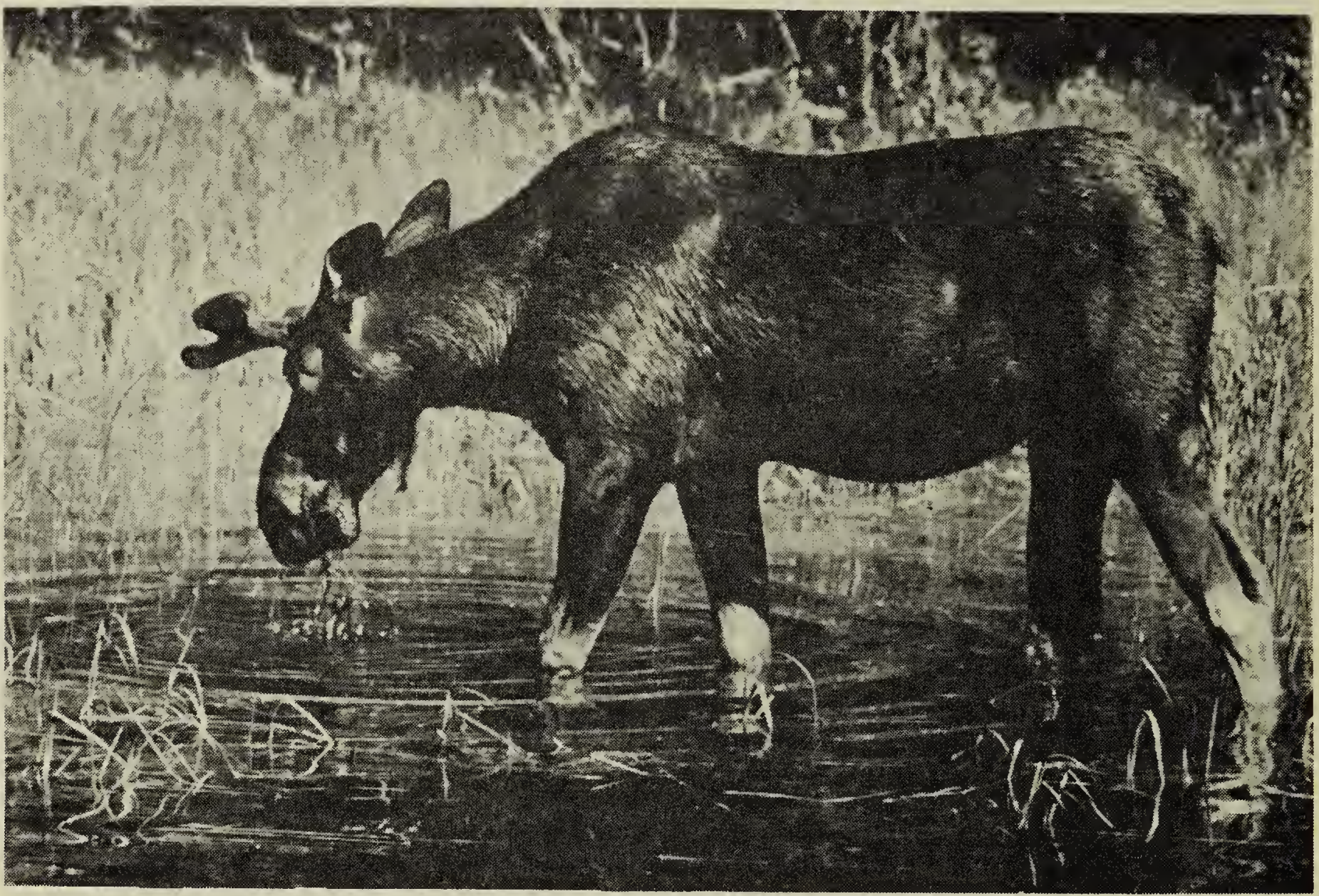

Fifty years of history have rolled by and the anniversary calls for appropriate celebrations but the occasion is more than just another birthday for those fifty years have witnessed a change which this province will never again experience. In a span of a lifetime Saskatchewan has seen a transformation of a relatively untouched prairie wilderness into a modern industrialized society. This is a good time to examine the effect of this change on wild animals that once flourished in such vast numbers across the western plains. The picture is a varied and a spotty one. Even at that early date the unrestrained exploitation of the wilderness by white man had done its deadly work. The Plains Buffalo which from time immemorial had dominated the scenery was already all but exterminated and many other species had been reduced to dangerously low levels. Many prairie residents will be surprised to learn, as I was, that less than a hundred years ago the Big Plains Grizzly was rather common on the plains and that a traveller in any one day's journey would seldom fail to see the Buffalo wolf; both animals were gone even before the main body of settlers moved in. These same travellers were unanimous that in early days wild animals showed little fear of man. The unsuspicious Kit Fox which on occasions is said to have almost been as trustful of man as a domestic dog paid for its familiarity with its life; once it covered all of the prairies and ranged as far north as the Saskatchewan River but by 1900 was already in a bad shape and now, too, is believed to be extinct in Canada.

The picture is not all black however, and some creatures that appeared doomed in earlier times have made some remarkable recoveries. W. T. Hornaday who made a survey of wildlife in 1904 was appalled by the dearth om many animals and in particular the scarcity of the coyote. But many bitter experiences, however, have taught the wild dog the folly of trusting man and his works and so today his kind is holding its own in the heart of the settled areas in spite of continued and often unwarranted 
persecution. The ability of any wild thing to survive depends on its ability to adapt itself to the changed environment but especially to learn how to live with man. The Red Fox with centuries of experience of that kind knows all the tricks and will undoubtedly fare better than his smaller cousin.

Another good example of successful adjustment is the Pronghorn Antelope. In primitive times this animal ranged over the whole vast prairie region from Lake Superior to the Rockies and was believed to be the most abundant large mammal on the plains. Mainly because of unrestrained slaughter (carcasses were shipped east by the carloads and sold at 25 cents each) its millions were reduced to a few pitiful thousands by 1900. Rigid protection put an end to this senseless destruction but the pronghorn itself had to solve the problem of getting through the railway and farm fences that were springingup with settlement. It seems that while the antelope can long leap it is poor at hurdling and for a time was actually threatened with annihilation until it learned to get through by ducking underneath the wires. People are still living who hunted the pronghorn within a few miles of Regina but the range of this animal today is confined solely to the south-west portion of the province.

Unlike the grizzly the Black Bear is much more adaptable animal and at times seems actually to prefer human company as witness the parks areas where bears often seem almost as numerous as the tourists. However he too has learned a thing or two about the ways of men and generally has retreated before the advance of civilization. A neighbor of mine used to hunt and trap bears regularly, within a mile of his home fifty years ago but today because of destruction of brush only stragglers appear on rare occasions.

Equally versatile creature which too supplemented the larder of the early pioneer and today appears as plentiful as ever is the lowly bunny. The Varying Hare is as much at home in the farmer's shelter belt as he is in the deepest woods. And in the open field one is almost certain of finding the Jack Rabbit. Last winter
I almost struck one with a car and that was, of all places, within the city limits of Saskatoon. While there may be some doubt whether rabbits who cannot resist the lure of the bright lights can ever overcome the hazards of city life those who stick to the natural habitat have plenty of open spaces on which to make a good living.

Among the hoofed tribe, the deer seem actually to have benefitted by the clearing of the land and in some regions are more common today than in earlier days. It's a different story with regard to Elk and the Moose. The latter is a denizen of the deep woods and has retreated with the forest as these are being pushed back by settlement. Early records of the elk indicate that in primitive times the range of this mammal extended practically from coast to coast. Seton believed that at its peak the population reached over 10 millions. As in so many other instances, wanton killing had reduced the numbers to only a few thousands by the end of the nineteenth century. The lesson of the vanished buffalo was beginning, to sink in men's mind and protection was given just in time. Today the elk seems to be quite well established and has even recovered some of its former territory.

In recent years the most striking phenomenon has been the recuperation of the Beaver, famous in the history of the fur trade. It's a resourceful animal, of few wants, and possessing great ability to flourish wherever there is wood and water. Yet incredible as it may seem, it actually was trapped close to the point of extinction by the end of the last century. One can only speculate on the future of less resilient creatures which today are subjected to the same trapping pressure. Once the otter was found in all parts of Canada but the encroachment of man has continued to reduce its numbers: the badger a common figure on the unscarred prairie in early days has disappeared from many areas; and even the Wolverine which knew no natural enemy has retreated into the fastnesses of the boreal forests before the advance of man.

An excellent example of the incompatability of wildlife with agri- 
culture is that provided by the Prairie Dogs whose cities of underground dwellings once stretched for hundreds of miles across the short-grass plains. Poisoned bait and guns in the hands of cattlemen and others soon cut down the population of millions to a few hundred confined to a small pocket south of Swift Current. No protection is given this tiny remnant so it seems only a matter of time when the prairie dog too will become a thing of the past in Canada. When that time comes, perhaps our neighbors to the south who have given sanctuary to the little animal in their National Parks will be indulgent enough to let us visit their country for a view of something which we ourselves didn't have the foresight to preserve.

In recent years there has come into fashion a doctrine known as wildlife management and with it a lot of glib talk maintaining populations of native species at arbitrary levels as if the numbers of any wild creature could be turned on and off at will. All that is necessary, it is held, is to juggle bag limits from season to season and introduce a few haphazard control measures which wouldn't interfere too much with hunting. Unfortunately the whole matter is not as simple as that. Even under primitive conditions of comparatively stable environment the struggle for life is so bitter that an animal can barely hold its own; it has all the burden it can bear, a trifle more and down it goes.

Any one or a combination of a multitude of disturbing factors that accompany settlement may be the proverbial last straw. The past century has been a score or so of native species pass into oblivion and it is entirely probable that the next will witness an equal number go down the same road and among them will be those that are now being "managed" to provide sport for the gunners. There is a growing feeling that the solution lies in the adoption of a broad conservation program on a national level to regulate the use of water, land, forest, wildlife and other natural resources to meet the expanding economy of the country and satisfy the recreational needs of the people without, at the same time jeopardizing the existence of any wild creature.

\section{BIRDS}

\author{
M. Brooker, \\ Grassy Lake, Sask.
}

Birds are delightful as a woman's hat, unpredictable as the weather, and endearing as no animal can be. Because they are not earth bound, they seem to dwell in a realm of their own that is all happiness, song, and colour.

The first time a Chickadee alighted on my hand to accept a Bluebottle fly. I was reminded of what my friend had said, years ago, when she cupped in her hand a tiny baby toad that could have sat comfortably on a dime. She said, "I feel like God with the world in the palm of my hand."

Of the five Chickadee's who feed from the upstairs bedroom window, three have learned to eat from the hand. Cupy, Stupy, and Spivlick. The last so named because of that little bit of bird talk "Spivlick" that he repeats insistently. Each bird has its own personality, its own approach. Cupy, alights square in the palm of the hand, looks up with awe at the great face above her, then deliberately turns her tiny tail and begins to eat the fly, while she clings to the finger tips. Stupy first alights on the screen that is hinged up, then does a flip and comes up on the under side of the hand, pears over, then swinging up, she snatches the fly, and flips to the birch tree to eat it. Spivlick snatches his fly on the wing, and rarely alights. And between "Spivlicks" he clicks sharply, spins like a top, and makes a great to do about nothing.

Crooker tail is distrustful, b u t would like to eat from the hand if he had the courage. So to bolster his ego he bosses all the others. Dee, who wades about in the snow on the outskirts of the feeding platter, is bossed by all, and says only, "Tsee Tsee." In gentle reproach.

At dawn every morning the Chickadee's come to be fed, regardless of the weather. Sometimes bewhiskered with frost, and their feet are cold. But they are always happy, singing, and amazingly durable. 